\title{
Preventive Effects of Polygonum minus Essential Oil on Cisplatin-Induced Hepatotoxicity in Sprague Dawley Rats
}

(Kesan Pencegahan Minyak Pati Polygonum minus ke atas Cisplatin-Aruhan Kehepatoksikan pada Tikus Sprague Dawley)

\author{
NORHASHIMA ABD RASHID, FARIDA HUSSAN, ASMAH HAMID, NURUL RAUDZAH ADIB RIDZUAN, \\ TEOH SEONG LIN \& SITI BALKIS BUDIN*
}

\begin{abstract}
Cisplatin is a chemotherapeutic agent widely used in treating various types of cancer. However, its usage is restricted due to the adverse hepatoxicity, as seen in approximately $36 \%$ of cancer patients receiving cisplatin treatment. Polygonum minus essential oil has high antioxidant capacity, and is enriched with terpenoids and phenolic compounds. The objective of this study was to investigate effects of P. minus essential oil (PmEO) supplementation on cisplatininduced hepatotoxicity in rats. Male rats were divided into seven different groups, namely: control $(C)$, cisplatininduced (CP), positive control with $\beta$-caryophyllene $150 \mathrm{mg} / \mathrm{kg}(B C P), P m E O 100 \mathrm{mg} / \mathrm{kg}$ (PmEO100CP), PmEO 200 $\mathrm{mg} / \mathrm{kg}$ (PmEO200CP), PmEO $400 \mathrm{mg} / \mathrm{kg}$ (PmEO400CP) and PmEO $400 \mathrm{mg} / \mathrm{kg}$ alone (PmEO400). PmEO and BCP was given orally for 14 days prior to a single dose cisplatin $(10 \mathrm{mg} / \mathrm{kg})$ injection on day 15 and rats were sacrificed on day 18. Liver enzymes, histology, ultrastructural morphology and oxidative stress markers such as glutathione, glutathione peroxidase, catalase, superoxide dismutase and malondialdehyde were assayed. Compared to controls, levels of transaminase enzymes, serum bilirubin and oxidative stress were all increased in CP, PmEO200CP and PmEO400CP groups. However, only PmEO100CP and BCP groups reduced these increases in level of transaminase enzymes and oxidative stress compared to CP group. On both light microscopic and ultrastructural examination, $C P$ and PmEO400CP groups showed hepatotoxicity, exhibited by cytoplasmic vacuolation, congested blood sinusoids and increased number of Kupffer cells. However, these changes were minimized in the PmEO100CP group. Therefore, we concluded that PmEO given at $100 \mathrm{mg} / \mathrm{kg}$ has preventive effect against cisplatin-induced hepatotoxicity in rats.
\end{abstract}

Keywords: Chemotherapeutic agent; cisplatin; liver enzymes; liver toxicity; Polygonum minus

\section{ABSTRAK}

Cisplatin adalah agen kemoterapi yang digunakan secara meluas untuk merawat pelbagai jenis kanser. Walau bagaimanapun, penggunaannya adalah sangat terhad disebabkan oleh berlakunya kehepatoksikan dalam kalangan kira-kira $36 \%$ pesakit kanser yang menerima rawatan cisplatin. Minyak pati Polygonum minus mempunyai keupayaan antioksidan yang tinggi dan diperkaya dengan terpenoid dan sebatian fenolik. Objektifkajian ini adalah untuk mengkaji kesan suplemen minyak pati P. minus (PmEO) ke atas cisplatin-aruhan kehepatoksikan di dalam tikus. Tikus jantan dibahagikan kepada tujuh kumpulan yang berbeza iaitu: kawalan $(C)$, cisplatin-aruhan $(C P)$, kawalan positif dengan $\beta$-caryophyllene $150 \mathrm{mg} / \mathrm{kg}$ (BCP), PmEO $100 \mathrm{mg} / \mathrm{kg}$ (PmEO100CP), PmEO $200 \mathrm{mg} / \mathrm{kg}$ (PmEO200CP), PmEO 400 $\mathrm{mg} / \mathrm{kg}$ (PmEO400CP) dan PmEO $400 \mathrm{mg} / \mathrm{kg}$ sahaja (PmEO400). PmEO dan BCP diberikan secara oral selama 14 hari sebelum dos tunggal cisplatin $(10 \mathrm{mg} / \mathrm{kg})$ disuntik pada hari ke 15 dan tikus dikorbankan pada hari $\mathrm{ke} 18$. Enzim hati, histologi, morfologi ultrastruktur dan penunjuk tekanan oksidatif seperti glutation, glutation peroksida, katalase, superoksida dismutase dan malondialdehid diasai. Berbanding dengan kawalan, tahap enzim transaminase, serum bilirubin dan tekanan oksidatif semuanya meningkat dalam kumpulan CP, PmEO200CP dan PmEO400CP. Walau bagaimanapun, hanya kumpulan PmEO100CP dan BCP mengurangkan tahap enzim transaminase dan tekanan oksidatif berbanding tikus aruhan cisplatin. Bagi kedua-dua pemeriksaan mikroskopik dan ultrastruktur, kumpulan CP dan PmEO400CP menunjukkan kehepatoksikan yang ditunjukkan oleh vakuolasi sitoplasma, sinusoid darah yang tersumbat dan peningkatan bilangan sel Kupffer. Walau bagaimanapun, perubahan ini diminimumkan dalam kumpulan PmEO100CP. Oleh itu, kami membuat kesimpulan bahawa PmEO diberikan pada $100 \mathrm{mg} / \mathrm{kg}$ mempunyai kesan pencegahan terhadap cisplatin-aruhan kehepatoksikan dalam tikus.

Kata kunci: Agen kemoterapi; cisplatin; enzim hati; ketoksikan hati; Polygonum minus 


\section{INTRODUCTION}

Cisplatin or cis-diamminedichloroplatinum (II) is a platinum complex with anticancer activity against various types of tumours including solid tumours of the head and neck and cancers in the reproductive system such as ovaries and testes (Katzung 2004). It is also clinically used to treat cancer of blood vessels, muscles, bones and soft tissue (Desoize 2002). Nevertheless, the therapeutic usage of cisplatin is particularly restricted due to side effects such as hepatotoxicity (El-Sayyad et al. 2009; Liao et al. 2008), nephrotoxicity (Pabla \& Dong 2008), ototoxicity (Rybak et al. 2009) and neurotoxicity (Barabas et al. 2008). It is now known that cisplatin significantly accumulates within human liver after administration and a high dose of the cisplatin produces hepatotoxicity characterized by impaired liver function, elevated levels of enzymatic biomarkers such as alanine aminotransferase (ALT) and aspartate aminotransferase (AST) (Palipoch \& Punsawad 2013), as well as hepatic necrosis, pericentral disorganization, and apoptotic changes (Attyah \& Ismail 2012). Transaminases are the most suitable biomarkers of liver toxicity and cellular disruption because they are located in the cytoplasm and are only secreted into the circulation after cellular disruption (İşeri et al. 2007). Increase in hepatic enzymes level in serum and bilirubin are also markers of perturbed liver function (Nasr 2013). El-Sayyad et al. (2009) and Kart et al. (2010) showed that cisplatin induced severe anomalies in liver tissue histology and the ultrastructure. Whilst the mechanisms underlying cisplatin-induced hepatoxicity remains poorly understood, oxidative stress is thought to primarily mediate cisplatininduced hepatotoxicity (Cetin et al. 2011).

In recent years, various natural products and medicinal plants were extensively studied for protective effects against human diseases and illnesses. These include Zingiber zerumbet (Hamid et al.2018), leaves of Plantago major (Hussan et al. 2015), Malaysian gelam honey (Lee et al. 2011) and Hibiscus sabdariffa (Idris et al. 2012) as potential protective agents and were proven to have high antioxidant capacity both in vivo and in vitro. Polygonum minus (syn. Persicaria minor), commonly known as kesum, is usually used as a folk medicine and flavoring ingredient in South East Asia countries, such as Vietnam, Laos, Indonesia and Thailand (Qader et al. 2011). It is an aromatic plant containing aliphatic aldehydes and according to Baharum et al. (2010), may produce high levels of essential oil ( 72.54\%). Furthermore, Ahmad et al. (2014) found that terpenoid metabolites were discovered in the leaves but not in the stem and root of this plant. A total of 35 terpenes were identified in the essential oil of $P$. minus, including a-humulene, a-curcumene $\beta$-caryophyllene, d-cadinene, farnesol and nerolidol (Baharum et al. 2010). Therapeutically, these sesquiterpenes were reported as anti-inflammatory agents (Fernandes et al. 2007), selective anticancer and antimicrobial agents against colorectal malignancies (Dahham et al. 2015) and cancer chemopreventive agents that protect cells from oxidant-induced DNA injury (Devi et al.2015) and antioxidant (Khan \& Sultana 2011) in both in vivo and in vitro settings. Despite these observations, it remains unclear whether $P$. minus essential oil can exert protect against cisplatin-induced hepatotoxicity and attenuate associated oxidative stress and ultrastructure damage in the liver.

The purpose of the present study was therefore to evaluate possible protective effect of $P$. minus essential oil (PmEO) on cisplatin-induced hepatotoxicity in adult male rats.

\section{MATERIALS AND METHODS}

\section{EXTRACTION OF ESSENTIAL OIL}

$P$. minus leaves were harvested from a local farm and authenticated at the Institutional Herbarium Department (No. UKMB40332). Fresh whole leaves $(10 \mathrm{~kg})$ of $P$. minus were subjected to hydrodistillation with $40 \mathrm{~L}$ of distilled water for $8 \mathrm{~h}$ using a Clevenger-type apparatus as previously described by Ahmad et al. (2014). Essential oil was collected over distilled water, separated, dried over nitrogen gas prior to storage in dark at $4^{\circ} \mathrm{C}$.

\section{GAS CHROMATOGRAPHY-MASS SPECTROMETRY (GC-MS) ANALYSIS}

For identification of volatile compounds in PmEO, samples were analyzed using the Clarus 600 GC-MS system (PerkinElmer, USA) (Ahmad et al. 2014). Volatile compounds were separated using a $30 \mathrm{~m} \times 0.25 \mathrm{~mm} \times 0.25$ $\mu \mathrm{m}$ Elite-5MS column. The injector port was heated to $250^{\circ} \mathrm{C}$ and the carrier gas was helium at a constant flow of $1 \mathrm{~mL} \cdot \mathrm{min}^{-1}$. All mass spectra were acquired in the electron impact mode (EI). The MS parameters were as follows: EI mode, an ionization voltage of $70 \mathrm{eV}$, an ion source temperature of $200^{\circ} \mathrm{C}$ and a scan range of $40-600 \mathrm{Da}$. The peaks were tentatively identified based on a library search using NIST and Wiley Registry 8 Edition.

\section{EXPERIMENTAL DESIGN}

Male Sprague Dawley rats $(n=42,180-200$ g) were kept in polypropylene cages with good ventilation under standard conditions (12/12 light/dark cycle at $21 \pm 2{ }^{\circ} \mathrm{C}$ and $50-70 \%$ humidity) and were acclimatized for 7 days before treatments. Standard rodent pellet and tap water were provided ad libitum. Rats were divided into seven different groups: control (C), cisplatin-induced (CP), positive control i.e. $\beta$-caryophyllene $150 \mathrm{mg} / \mathrm{kg}+$ cisplatin-induced (BCP), PmEO $100 \mathrm{mg} / \mathrm{kg}$ + cisplatin-induced (PmEO100CP), PmEO $200 \mathrm{mg} / \mathrm{kg}$ + cisplatin-induced (PmEO200CP), PmEO $400 \mathrm{mg} / \mathrm{kg}$ + cisplatin-induced (PmEO400CP) and PmEO $400 \mathrm{mg} / \mathrm{kg}$ alone (PmEO400). Doses, duration of essential oil and $\beta$-caryophyllene was given according to Damião et al. (2013), Ebada (2018) and Cho et al. (2007). PmEO were given orally for 14 consecutive days prior to 
a single dose of cisplatin (10 mg/kg ip.) injection on day 15. All animals were sacrificed on day 18. Blood samples were collected directly via cardiac puncture and transferred into separate test tubes. Liver tissues were excised, rinsed gently with ice-cold normal saline, weighed and divided into four parts for further analyses. The liver weight/body weight ratio was calculated according to the following formula, organ ratio $(\%)=$ organ weight $\times 100 /$ body weight (Nasr 2013). All animal procedures adhered to the ethical approval from institutional animal ethnical committee (FP/ ANAT/2014/FAIZAH/26-NOV./632-NOV.-2014-SEPT.-2017).

\section{LIVER BIOMARKERS}

Blood sample was centrifuged at $3000 \mathrm{rpm}$ for $15 \mathrm{~min}$, and the serum was separated and used within $48 \mathrm{~h}$ for estimation of transaminase enzymes. ALT and AST activity were estimated by assessing the amount of pyruvate or oxaloacetate produced (Nasr 2014). Alkaline phosphatase (ALP) and bilirubin were measured as previously described (Sarhan et al. 2014; Schmidt \& Eisenburg 1975).

\section{ANALYSIS OF LIVER OXIDATIVE STRESS}

A portion of rat liver was homogenized in $10 \%$ phosphate buffer saline (0.05 M, pH7.4) and centrifuged at 15,000 $\times \mathrm{g}$ for $15 \mathrm{~min}$ at $4^{\circ} \mathrm{C}$. The supernatant was collected and used for measurement of GSH, SOD Cat, GPx, MDA, protein carbonyl and 8-hydroxydeoxyguanosine (8-OHdG). The antioxidant markers GSH, SOD Cat, GPx, MDA, protein carbonyl and 8-OHdG were all measured using commercial ELISA kits (Cayman Chemical, USA and Elabscience, China) according to the manufacturer guidelines.

\section{HISTOLOGY}

Liver tissues were fixed in $10 \%$ neutral formalin for $48 \mathrm{~h}$, processed in ascending grades of alcohol and embedded in paraffin blocks. Sections of $4 \mu \mathrm{m}$ were obtained from the prepared blocks using a microtome (Leica RM2135, Germany) and stained with haematoxylin and eosin. These preparations were visualized using a Leica DMRXA2 microscope (Germany).

\section{ELECTRON MICROSCOPIC EXAMINATION}

Liver tissues $\left(1 \mathrm{~mm}^{3}\right)$ from each animal were cut and immersed in $3 \%$ glutaraldehyde in $0.1 \mathrm{M}$ phosphate buffer at $4^{\circ} \mathrm{C}$ and were fixed in $1 \%$ osmium tetraoxide for $2 \mathrm{~h}$ at $4^{\circ} \mathrm{C}$ (Nasr 2013). The samples were dehydrated via ascending grades of ethanol, treated with a propylene oxide solution and embedded in a mixture of 1:1 Epon-Araldite for $1 \mathrm{~h}$. Samples were polymerized for $24 \mathrm{~h}$ at $65^{\circ} \mathrm{C}$. One $\mu \mathrm{m}$ sections were cut, mounted on glass slides and stained with buffered toluidine blue. Appropriate areas were selected and cut (50 - $60 \mathrm{~nm}$ ), then mounted on copper grids, double stained with uranyl acetate and lead citrate to examine under the electron microscope (FEI TECNAI BIOTWIN, $120 \mathrm{kv}$, Netherland).

\section{STATISTICAL ANALYSIS}

All values are expressed as means \pm SEM after analysis using Statistical Package for the Social Sciences version 23 (SPSS Inc, IL, USA). The data with homogeneous intra-group variances were subjected to one-way analysis variance (ANOVA) followed by post-hoc Tukey's test. $P$ value of 0.05 or less was considered statistically significant.

\section{RESULTS}

VOLATILE COMPOUND OF LEAVES FROM P. minus ESSENTIAL OIL

Most of the volatiles compounds identified in $P$. minus yellowish-essential oil were aldehydes, sesquiterpenes and organic acids as shown in Table 1. A total of 37 compounds were identified; with dodecanal and decanal being the most dominant compounds (39.4\% and $10.4 \%$, respectively). Sesquiterpene identified in the P. minus essential oil include $8.61 \%$ cyclolongifolene oxide, $3.3 \% \alpha$-caryophellene, $1.13 \% \alpha$-bergamotene, $0.72 \%$ seychellene, $0.63 \%$ $\beta$-caryophellene, $0.58 \%$ velencene, $0.56 \%$ drimenol. The relative concentrations of several classes of volatile compounds identified in $P$. minus essential oil are shown in Table 2.

\section{EFFECT OF CISPLATIN AND PMEO ON MORTALITY RATE AND TOXICITY IN RATS}

Table 3 shows the mortality rate and toxicity symptoms observed in experimental rats. Regardless of type of treatment, no mortality was observed in all experimental groups at endpoint. Cisplatin and PmEO400CP-induced rats exhibited cholinergenic toxicity symptoms such as lacrimation, tremor, piloerection, reduced food and drink intake and hypoactivity on day 18 . No signs of toxicity were however observed in control rats. Food and water intake on the day 18 was significantly reduced in $\mathrm{CP}, \mathrm{BCP}$, PmEO200CP and PmEO400CP groups compared to the controls and PmEO400-treated rats (Table 4).

\section{EFFECT OF CISPLATIN AND PMEO ON BODY WEIGHT OF RATS}

There was a significant reduction $(p<0.05)$ in the body weight of CP group compared to the control group on day 17 and 18 (Figure 1). Combination of PmEO (all doses) and BCP with cisplatin also caused a significant $(p<0.05)$ reduction in body weight of rats compared to control rats on day 17 and 18 .

\section{EFFECT OF CISPLATIN AND PMEO ON LIVER WEIGHT IN RATS}

Effects of PmEO on the liver weight and liver weightto-body weight ratio in rats are shown in Table 5. Both liver weight and liver weight-to-body weight ratio were significantly reduced in cisplatin-induced rats compared to the control rats $(p<0.05)$. However, liver weight/ body weight ratio was significantly increased in $\mathrm{BCP}$, 
TABLE 1 . Volatile compound of $P$. minus leaves in essential oil

\begin{tabular}{|c|c|c|c|}
\hline $\begin{array}{c}\text { Peak } \\
\text { No. }\end{array}$ & Compound* & $\begin{array}{l}\text { Retention } \\
\text { time }\end{array}$ & Percentage $* *$ \\
\hline \multicolumn{4}{|c|}{ Aldehyde } \\
\hline 1 & Decanal & 14.791 & 10.396 \\
\hline 2 & Undecanal & 17.469 & 0.503 \\
\hline 3 & Dodecanal & 20.348 & 39.384 \\
\hline 4 & Tetradecanal & 24.95 & 1.194 \\
\hline 5 & Pentadecanal & 38.172 & 0.309 \\
\hline 6 & Hexadecanal & 39.914 & 0.681 \\
\hline \multicolumn{3}{|c|}{ Alcohol } & \multirow{5}{*}{$\begin{array}{l}0.957 \\
1.092 \\
0.282 \\
0.046\end{array}$} \\
\hline 7 & 1-Dodecanol & 19.073 & \\
\hline 8 & 1-Undecanol & 22.382 & \\
\hline 9 & 1-Dodecen-3-ol & 33.285 & \\
\hline \multirow[t]{2}{*}{10} & a-(Z)-Bergamotol & 24.793 & \\
\hline & \multicolumn{3}{|l|}{ Terpenoid (sesquiterpene) } \\
\hline 11 & Isocaryophyllene & 19.843 & 0.438 \\
\hline 12 & $\alpha$-Bergamotene & 20.614 & 0.66 \\
\hline 13 & $\alpha$-Caryophyllene & 21.208 & 3.294 \\
\hline 14 & Seychellene & 21.787 & 0.72 \\
\hline 15 & $\beta$-Farnesene & 21.099 & 0.476 \\
\hline 16 & Velencene & 21.989 & 0.576 \\
\hline 17 & $\alpha$-Bergamotene & 22.695 & 0.299 \\
\hline 18 & $\alpha$-Panasinsen & 22.695 & 0.279 \\
\hline 19 & $\alpha$-Bergamotene & 23.337 & 0.169 \\
\hline 20 & $\beta$-Caryophyllene & 24.198 & 0.627 \\
\hline 21 & trans-Z- $\alpha$-Bisabolene epoxide & 24.859 & 0.192 \\
\hline 22 & Cyclolongifolene oxide & 25.601 & 8.608 \\
\hline 23 & $\beta$-Bisabolol & 26.243 & 0.277 \\
\hline 24 & Drimenol & 28.774 & 0.557 \\
\hline 25 & Isolongifolol & 28.774 & 0.342 \\
\hline \multirow[t]{2}{*}{26} & Drimenin & 34.999 & 0.386 \\
\hline & \multicolumn{3}{|c|}{ Organic acid } \\
\hline 27 & Dodecanoic acid & 25.739 & 2.457 \\
\hline 28 & 4,7-Octadecadiynoic acid & 33.44 & 0.703 \\
\hline 29 & Hexadecanoic acid & 33.633 & 1.87 \\
\hline 30 & $\alpha$-Linolenic acid & 36.631 & 1.935 \\
\hline 31 & Octadecanoic acid & 37.016 & 0.279 \\
\hline \multicolumn{4}{|c|}{ Aliphatic compound } \\
\hline 32 & Naphthalenone, 3, 5, 6, 7, 8, 8a-octahydro-2,5,8a-6-(1-methylethenyl)- & 31.167 & 0.24 \\
\hline 33 & Phytol & 35.824 & 0.806 \\
\hline 34 & 1H-Inden-1-one,5-(1,1-dimethylethyl)-2,3-dihydro-3,3-dimethyl & 37.2 & 0.807 \\
\hline 35 & 3,7,11,14,18-Pentaoxa-2,19-disilaeicosane,2,2,19,19-tetramethyl- & 40.821 & 0.355 \\
\hline 36 & Eicosane & 41.161 & 0.212 \\
\hline 37 & Bicyclo[4.3.0]nonane, 5a-iodomethyl-1a-isopropenyl-4a,5a-dimethyl- & 41.665 & 0.618 \\
\hline
\end{tabular}

*As identified by GC-MS Software; names according to NIST mass spectral library. **Percentage of each compound is calculated as peak area of analyte divided by peak area of total ion chromatogram multiply by 100

TABLE 2. The relative concentrations of volatile compounds in P. minus essential oil

\begin{tabular}{cc}
\hline \multirow{2}{*}{ Chemical class of compound } & Essential oil \\
\cline { 2 - 2 } & \% Relative area \\
\hline Aldehyde & 52.47 \\
Sesquiterpenes & 17.9 \\
Organic Acid & 7.24 \\
Aliphatic compound & 3.04 \\
Alcohol & 2.38 \\
\hline
\end{tabular}


TABLE 3. Mortality and toxicity symptoms in cisplatin and PmEO-induced rats

\begin{tabular}{|c|c|c|}
\hline Group & Mortality & Toxicity symptom \\
\hline Control & $0 / 6$ & None \\
\hline \multirow[t]{6}{*}{ Cisplatin } & $0 / 6$ & Lacrimation $(n=2)$ \\
\hline & & Tremor $(n=0)$ \\
\hline & & Piloerection $(n=6)$ \\
\hline & & Drink a lot $(n=2)$ \\
\hline & & Less food intake $(n=6)$ \\
\hline & & Hipoactivity $(n=6)$ \\
\hline \multirow[t]{6}{*}{$\mathrm{BCP}$} & $0 / 6$ & Lacrimation $(n=0)$ \\
\hline & & Tremor $(n=0)$ \\
\hline & & Piloerection $(n=3)$ \\
\hline & & Drink a lot $(n=2)$ \\
\hline & & Less food intake $(n=5)$ \\
\hline & & Hypoactivity $(n=3)$ \\
\hline \multirow[t]{6}{*}{ PmEO100CP } & $0 / 6$ & Lacrimation $(n=0)$ \\
\hline & & Tremor $(n=0)$ \\
\hline & & Piloerection $(n=4)$ \\
\hline & & Drink a lot $(n=2)$ \\
\hline & & Less food intake $(n=5)$ \\
\hline & & Hypoactivity $(n=3)$ \\
\hline \multirow[t]{6}{*}{ PmEO200CP } & $0 / 6$ & Lacrimation $(n=0)$ \\
\hline & & Tremor $(n=0)$ \\
\hline & & Piloerection $(n=6)$ \\
\hline & & Drink a lot $(n=1)$ \\
\hline & & Less food intake $(n=5)$ \\
\hline & & Hypoactivity $(n=6)$ \\
\hline \multirow[t]{6}{*}{ PmEO400CP } & $0 / 6$ & Lacrimation $(n=2)$ \\
\hline & & Tremor $(n=0)$ \\
\hline & & Piloerection $(n=6)$ \\
\hline & & Drink a lot $(n=0)$ \\
\hline & & Less food intake $(n=6)$ \\
\hline & & Hypoactivity $(n=6)$ \\
\hline \multirow[t]{5}{*}{ PmEO400 } & $0 / 6$ & Lacrimation $(n=0)$ \\
\hline & & Tremor $(n=0)$ \\
\hline & & Piloerection $(n=0)$ \\
\hline & & Drink a lot $(n=0)$ \\
\hline & & Hypoactivity $(n=6)$ \\
\hline
\end{tabular}

TABLE 4. Effects of cisplatin and PmEO on food and drink intake in rats

\begin{tabular}{lccccccc}
\hline Group & Control & Cisplatin & BCP & PmEO100CP & PmEO200CP & PmEO400CP & PmEO400 \\
\hline Food intake Day 15 & $21.6 \pm 1.3$ & $21.3 \pm 1.5$ & $19.5 \pm 1.7$ & $23.9 \pm 1.1$ & $20.2 \pm 1.4$ & $20.1 \pm 1.5$ & $20.6 \pm 1.5$ \\
Food intake Day 18 & $24.0 \pm 1.1$ & $3.8 \pm 1.4^{\mathrm{a}}$ & $6.0 \pm 2.1^{\mathrm{a}}$ & $4.1 \pm 2.5^{\mathrm{a}}$ & $3.3 \pm 2.2^{\mathrm{a}}$ & $3.8 \pm 2.1^{\mathrm{a}}$ & $21.2 \pm 0.4^{\mathrm{bcdef}}$ \\
Drink intake Day 15 & $30.3 \pm 2.6$ & $31.0 \pm 1.0$ & $26.8 \pm 3.0$ & $31.0 \pm 1.1$ & $32.8 \pm 1.5$ & $33.3 \pm 3.1$ & $34.3 \pm 2.8$ \\
Drink intake Day 18 & $30.0 \pm 1.9$ & $19.3 \pm 6.5$ & $18.3 \pm 3.9$ & $29.8 \pm 2.8$ & $12.3 \pm 4.1^{\text {ad }}$ & $11.0 \pm 2.7^{\text {ad }}$ & $32.3 \pm 1.6^{\text {ef }}$ \\
\hline
\end{tabular}

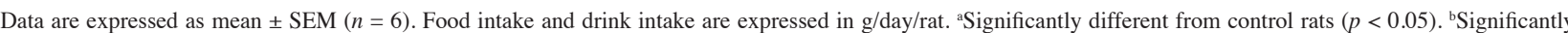
different from cisplatin-induced rats $(p<0.05)$. ${ }^{\mathrm{c} S i g n i f i c a n t l y ~ d i f f e r e n t ~ f r o m ~ B C P-t r e a t e d ~ r a t s ~}(p<0.05)$. ${ }^{\mathrm{d} S i g n i f i c a n t l y ~ d i f f e r e n t ~ f r o m ~ P m E O 100 C P-t r e a t e d ~ r a t s ~}(p<0.05)$.

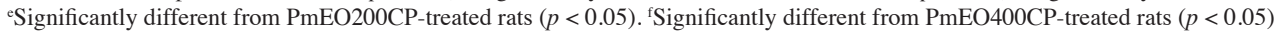




\section{Effect of Cisplatin and PmEO on Body Weight of Rats}

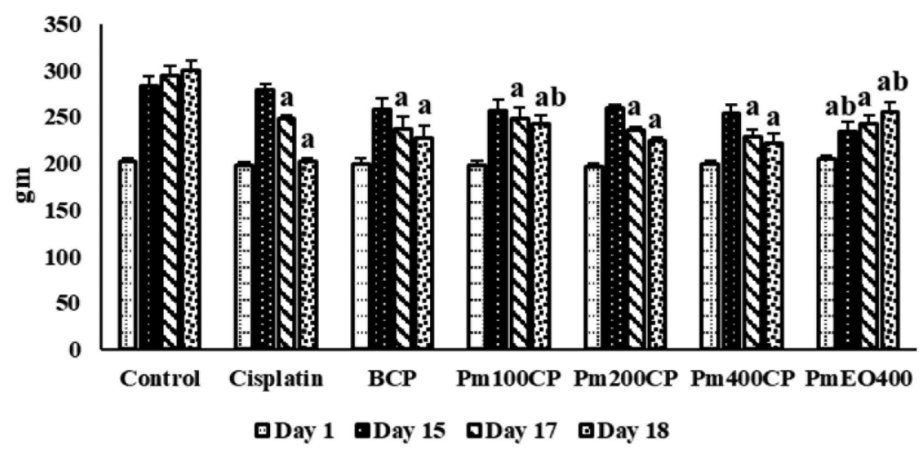

FIGURE 1. Effects of cisplatin and PmEO on body weight $(\mathrm{g})$ in rats (Mean $\pm \mathrm{SEM})$. CP group is asignificantly different from Control group at $p<0.05$ on the day 17 and 18. Weight of BCP, PmEO+Cisplatin-induced group (PmEO100CP, PmEO200CP, PmEO400CP) is asignificantly reduced at $p<0.05$ on the day 17 and 18 compared to Control. Meanwhile PmEO100CP is ${ }^{\mathrm{b}}$ significantly different at $p<0.05$ on the day 18 compared to $\mathrm{CP}$ group. However, PmEO400 showed significant difference against control and $\mathrm{CP}$ group at $p<0.05$ on the day 15,17 and 18

TABLE 5. Effects of cisplatin and PmEO on liver weight and liver weight/body weight ratio in rats

\begin{tabular}{cccccccc}
\hline Group & Control & Cisplatin & BCP & PmEO100CP & PmEO200CP & PmEO400CP & PmEO400 \\
\hline Liver Weight $(\mathrm{g})$ & $12.10 \pm 0.38$ & $7.20 \pm 0.09^{\mathrm{a}}$ & $8.80 \pm 0.64^{\mathrm{ab}}$ & $9.75 \pm 0.23^{\mathrm{ab}}$ & $9.00 \pm 0.13^{\mathrm{ab}}$ & $8.97 \pm 0.17^{\mathrm{ab}}$ & $10.30 \pm 0.41^{\mathrm{ab}}$ \\
Final Body & $300.50 \pm$ & $201.83 \pm$ & $227.50 \pm$ & $242.17 \pm$ & $224.17 \pm$ & $221.83 \pm$ & $255.33 \pm$ \\
Weight (g) & 9.90 & $3.50^{\mathrm{a}}$ & $12.40^{\mathrm{a}}$ & $9.30^{\mathrm{ab}}$ & $2.98^{\mathrm{a}}$ & $9.50^{\mathrm{a}}$ & $9.94^{\mathrm{ab}}$ \\
$\begin{array}{c}\text { Liver weight/ } \\
\text { body weight }\end{array}$ & $4.03 \pm 0.01$ & $3.52 \pm 0.02^{\mathrm{a}}$ & $3.85 \pm 0.09^{\mathrm{b}}$ & $4.04 \pm 0.06^{\mathrm{b}}$ & $4.00 \pm 0.02^{\mathrm{b}}$ & $4.06 \pm 0.10^{\mathrm{b}}$ & $4.03 \pm 0.03^{\mathrm{b}}$ \\
Ratio (\%) & & & & & & & \\
\hline
\end{tabular}

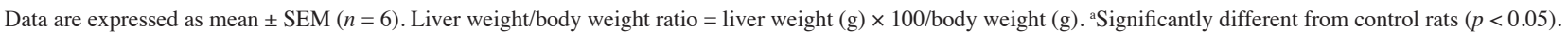
bignificantly different from cisplatin-induced rats $(p<0.05)$

PmEO100CP, PmEO200CP and PmEO400CP and PmEO400 group compared to CP group.

\section{EFFECT OF CISPLATIN AND PMEO ON LIVER BIOMARKERS IN RATS}

ALP, AST, ALT, conjugated bilirubin and total bilirubin levels were all significantly increased in the PmEO400CP and cisplatin-induced rats when compared to the control rats at $p<0.05$. However, a significant reduction $(p<0.05)$ was observed for ALP, AST and ALT in PmEO100 and PmEO200 groups when compared to the cisplatin-induced rats. Liver biomarkers (ALP, ALT, conjugated bilirubin and total bilirubin) were all significantly elevated in PmEO200CP, PmEO400CP and PmEO400 groups compared to BCP and PmEO100CP-treated rats. PmEO400CP also showed a significant increase in serum bilirubin as compared to the PmEO200CP group. PmEO400 alone group showed a significant reduction $(p<0.05)$ in AST, ALT and serum bilirubin as compared to cisplatin-induced rats (Figure 2).

\section{EFFECT OF CISPLATIN AND PMEO ON OXIDATIVE STRESS}

GSH, SOD, and GPx activities significantly lowered in CP, PmEO200 and PmEO400 groups when compared to the control, BCP and PmEO100CP groups. CAT activity level was also lowered in CP, PmEO200CP and PmEO400CP groups compared to the control and $\mathrm{BCP}$-treated rats $(p<$ 0.05). MDA, protein carbonyl and 8-OHdG levels were significantly increased in $\mathrm{CP}, \mathrm{PmEO} 200$ and PmEO400 groups compared to the control and $\mathrm{BCP}$-treated rats $(p$ $<0.05$ ) indicating enhanced lipid peroxidation, protein oxidation and oxidant-induced DNA damage. However, the levels of GSH, GPx, CAT, SOD and MDA showed no significant difference against $\mathrm{BCP}, \mathrm{PmEO} 100 \mathrm{CP}$ and control rats. A significant reduction $(p<0.05)$ was observed in all oxidative stress marker (GSH, GPx, CAT, SOD, MDA) in control, BCP and PmEO100CP compared to CP group (Figure 3).

\section{EFFECT OF CISPLATIN AND PMEO ON LIVER HISTOLOGY}

Liver histology with haematoxylin and eosin staining as shown in Figure 4(a); showed control hepatic tissues with well-organized radiating cords of hepatocytes around the central vein and narrow sinusoids. Endothelial cells and Kupffer cells were well lined in the blood sinusoids. Unlike this, the group receiving cisplatin (Figure 4(b)) showed dilatation and congestion of central vein and blood sinusoids in the liver. Accumulation of inflammatory 


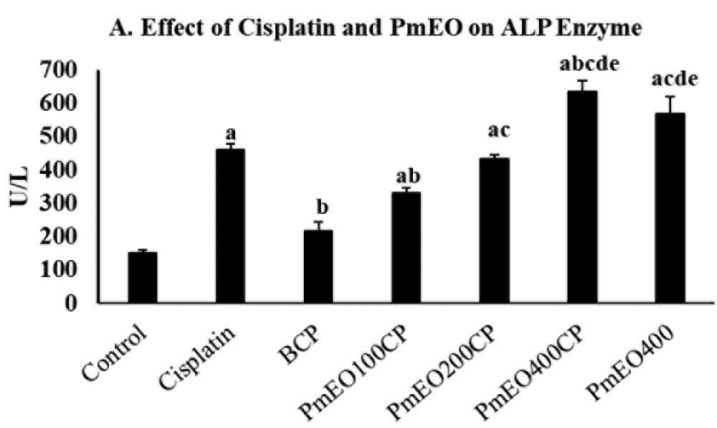

C. Effect of Cisplatin and PmEO on ALT Enzyme

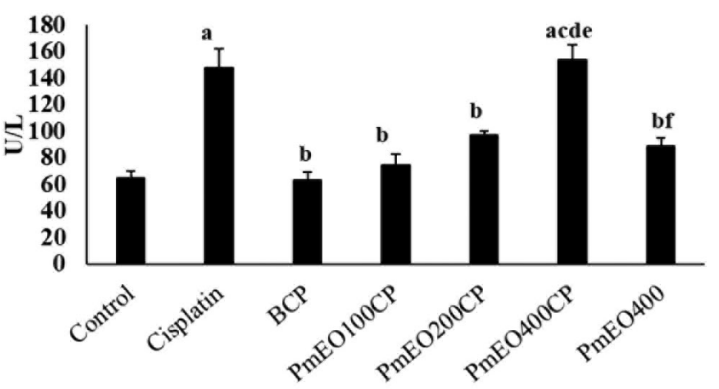

B. Effect of Cisplatin and PmEO on AST Enzyme

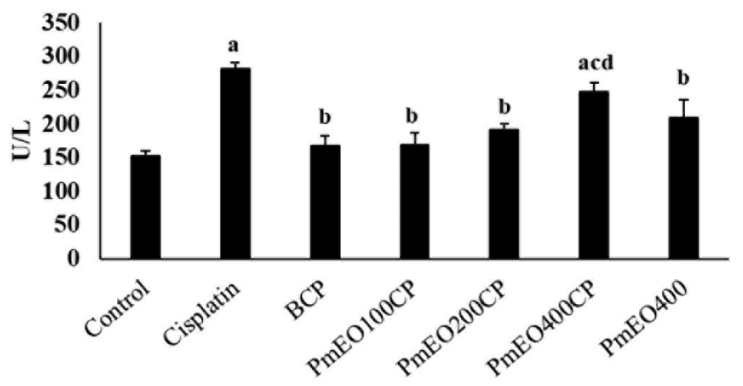

D. Effect of Cisplatin and PmEO on Direct Bilirubin (Conjugated Bilirubin)

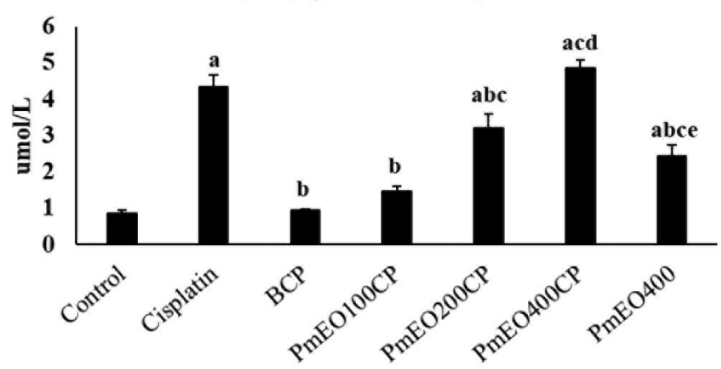

E. Effect of Cisplatin and PmEO on Total Bilirubin

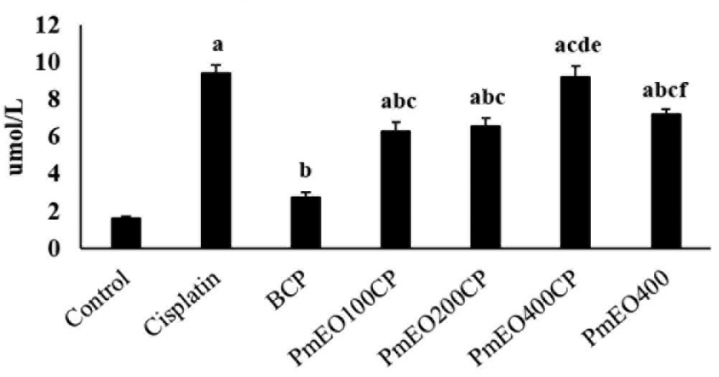

FIGURE 2. Effect of cisplatin and PmEO on liver biomarkers in rats. Values are mean $\pm \operatorname{SEM}(n=6)$. ${ }^{\text {SSignificantly }}$

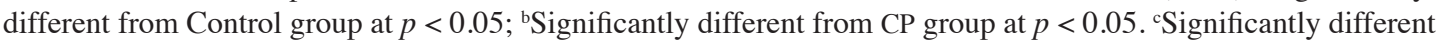
from BCP group at $p<0.05$. ${ }^{\mathrm{d}}$ Significantly different from PmEO100CP group at $p<0.05$. ${ }^{\mathrm{e}}$ Significantly different from PmEO200CP group at $p<0.05$. Significantly different from PmEO400CP group at $p<0.05$. ALP - alkaline phosphatase, ALT - alanine aminotransferase, AST - aspartate aminotransferase

cells and apoptotic nuclei were also observed in the centrilobular zone. In BCP group and PmEO100CP-treated rats (Figure 4(c), 4(d)), a well-organized radiating cords of hepatocytes around the central vein were observed. However, mild dilatation of blood sinusoids with relative increase in the number of binucleated hepatocytes and Kupffer cells were observed. PmEO200CP-treated rats showed dilated blood sinusoids (Figure 4(e)) with increased number of Kupffer cells and binucleated cells, along with poorly-organized hepatocytes. PmEO400CPtreated rats (Figure 4 (f)) showed dilated blood sinusoids around the congested and dilatation of central vein. The hepatocytes were not well-organized and apoptotic nuclei can be easily seen in the centrilobular zone. PmEO400 (Figure 4(g)) showed mild dilatation of blood sinusoids with increase number of Kupffer cells and the hepatocytes were disorganized.

\section{EFFECT OF CISPLATIN AND PMEO ON ELECTRON MICROSCOPIC STUDY}

Electron microscopic examination showed normal polygonal-shaped hepatocytes with central oval nucleus in the control rats (Figure 5(a)). The nucleus exhibited a discontinued nuclear envelope, thick nucleolus and condensed heterochromatin on the inner side of the nuclear envelope around the nuclear pores. Round and oblong-shaped mitochondria were scattered in groups, with parallel rough endoplasmic reticulum (RER) cisternae, few lysosomes and glycogen masses and hepatocyte membrane in normal hepatocytes. In cisplatin-induced rats, however, the central nucleus was tremendously irregular in shape (Figure 5(b)) and the nucleus exhibited few variablesized of heterochromatin masses on the inner side of the nuclear envelope. Increased number of variable sizes and shapes of mitochondria along with vesicular dilated 

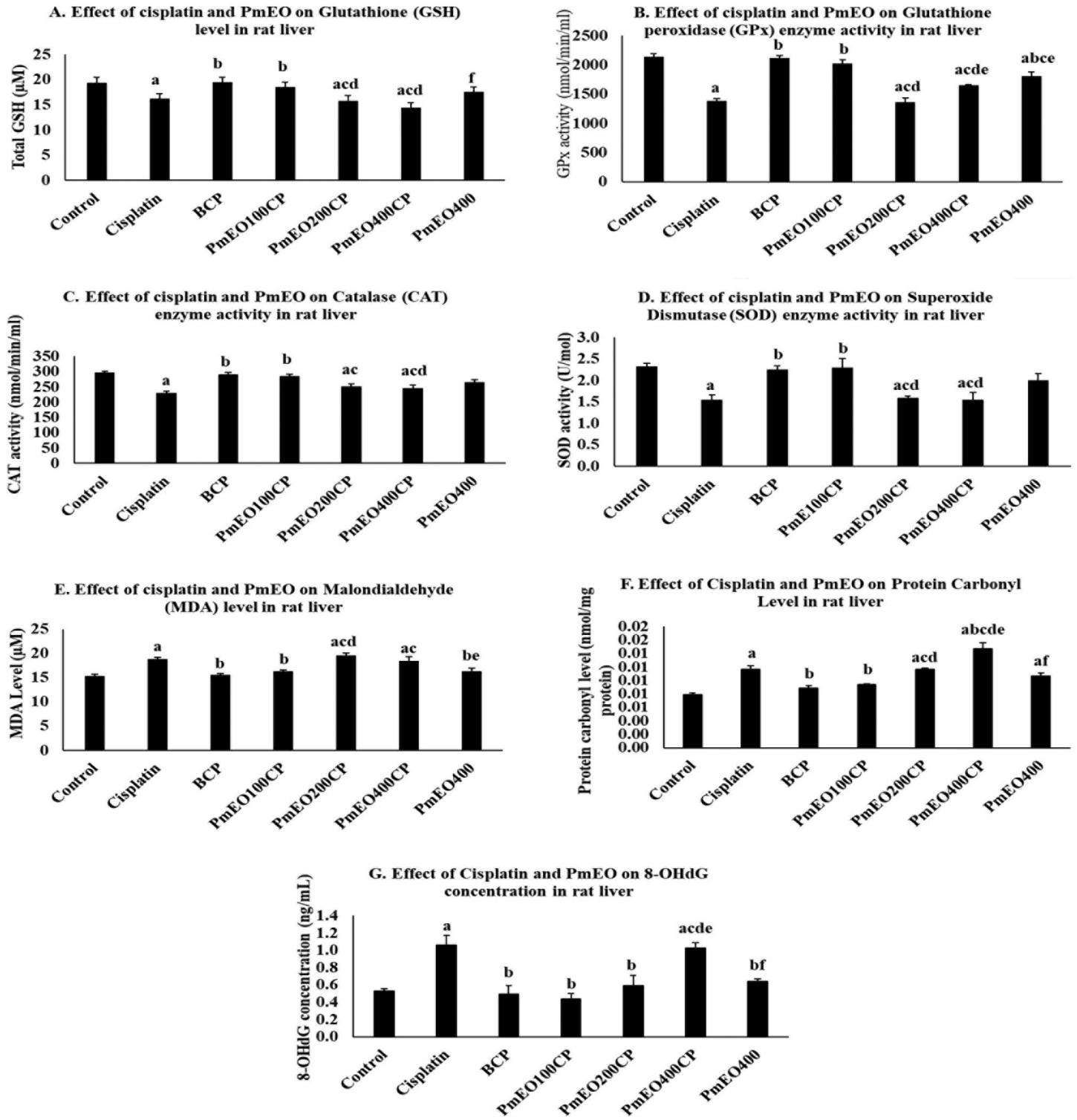

FIGURE 3. Effect of cisplatin and PmEO on liver antioxidant enzymes and lipid peroxidation in rats. Values are mean

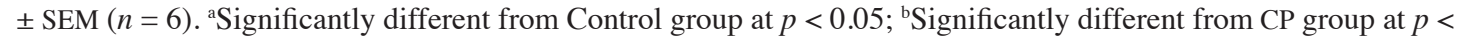
0.05. 'Significantly different from BCP group at $p<0.05$. 'Significantly different from PmEO100CP group at $p<0.05$.

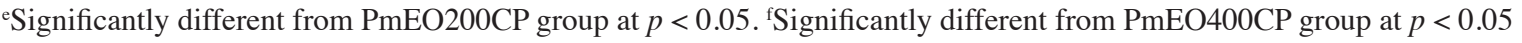

RER were seen inside the cytoplasm of the hepatocyte. In $\mathrm{BCP}$ and PmEO100CP groups, the hepatocytes had a regular polygonal shape and large oval nucleus with thick nucleolus (Figure 5(c), 5(d)). Numerous round mitochondria, parallel RER cisternae, lysosomes, glycogen masses and hepatocyte membrane were also observed in both BCP and PmEO100CP-treated rats. In PmEO200CPtreated rats (Figure 5(e)), the nucleus exhibited irregular shape of envelope with dense heterochromatin and fewer mitochondria were seen to fill in the space of the cytoplasm as compared to $\mathrm{BCP}$ and PmEO100CP-treated rats. A macrophage, large-sized of phagosome and vesicular dilated RER cisternae were also observed in the cytoplasm as well. In PmEO400CP-treated rats, the hepatocytes attained small size and a central nucleus with irregular outline
(Figure 5(f)). The nuclear part showed a little amount of condensed heterochromatin within the nucleoplasm. Few lysosomes, round mitochondria and vesicular dilated RER cisternae were observed in PmEO400CP-treated rats. PmEO400-treated rats (Figure 5(g)) showed congested cytoplasm with rounded mitochondria and RER cisternae. Few lysosomes and hepatocyte membrane also can be seen.

\section{DISCUSSION}

Cisplatin is a prominent anticancer drug mainly used to treat solid tumors. However, its usage is limited due to toxicity on the liver, seen on approximately $36 \%$ of cancer patients after a single dose of treatment (Al-Malki \& Sayed 2014). El-Sayyad et al. (2009) stated that the liver is known 

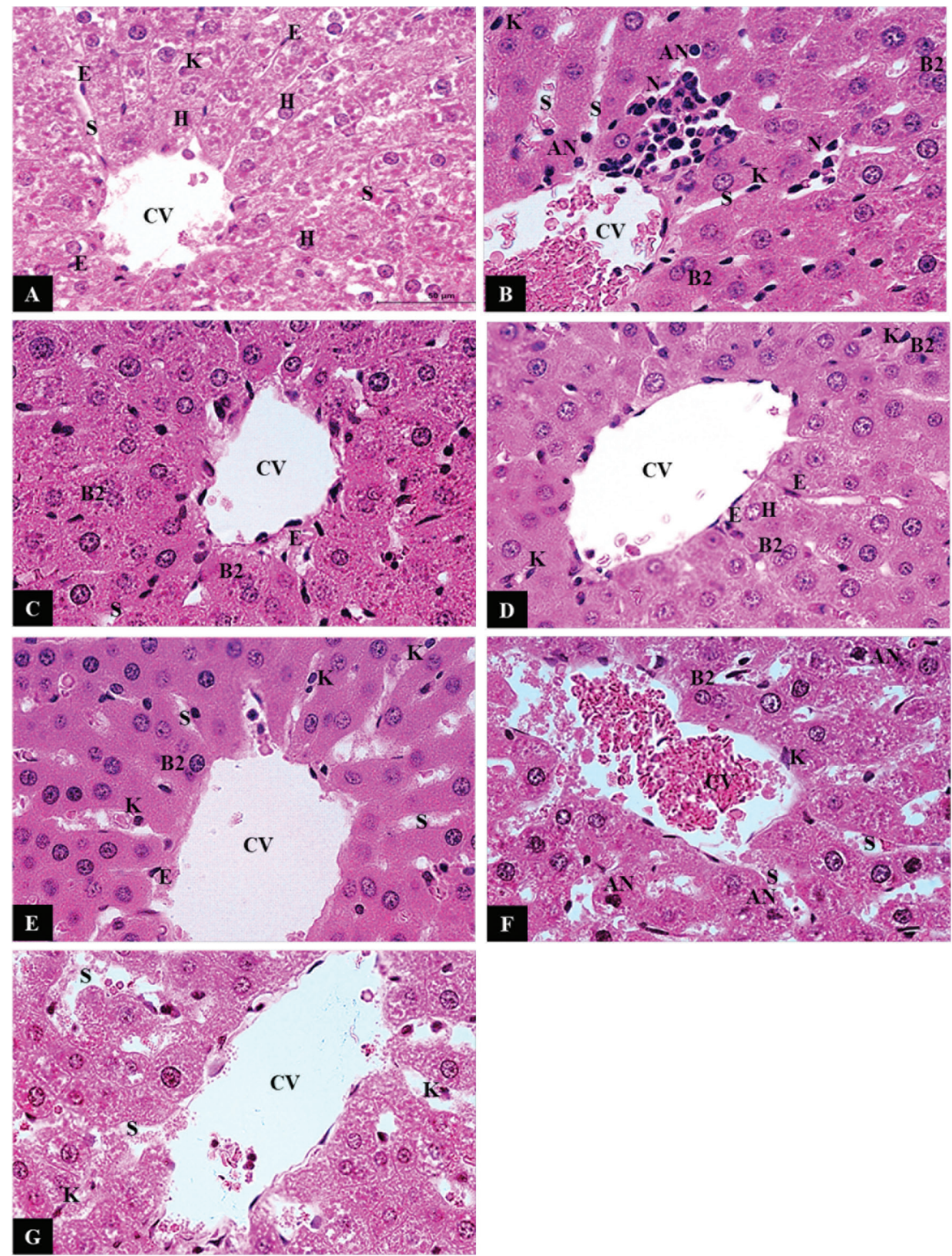

FIGURE 4. Histological changes in the rat liver. (A) A control liver with normal architecture of radiating hepatocyte-cords (H) around the central vein $(\mathrm{CV})$ and narrow blood sinusoids (S) with few binucleated hepatocytes (B2). Endothelial cells and Kupffer cells (K) lined in the blood sinusoids; (B) Dilated congested central vein and blood sinusoids, few Kupffer cells and apoptotic nuclei (AN) can be seen with accumulation of inflammatory cells $(\mathrm{N})$ appear in the CP group; (C) BCP group shows almost similar architecture of hepatocytes with control group; (D) narrow blood sinusoids with endothelial cells (E), increasing number of Kupffer cells and binucleated hepatocytes were seen in PmEO100CP group; (E) Mild dilated blood sinusoids, few Kupffer cells with binucleated hepatocytes were observed in PmEO200CP group; (F) Dilated congested blood sinusoids, Kupffer cells, binucleated hepatocytes and apoptotic nuclei can be seen in PmEO400CP group; and (G) PmEO400 shows dilated blood sinusoids, increasing number of Kupffer cells and irregular structure of central vein (Hematoxylin and eosin $\times 400$; scale bars $50 \mu \mathrm{m}$ )

to accumulate significant amount of cisplatin, after kidney. Therefore, hepatotoxicity can occur easily after high dose administration of cisplatin $(10 \mathrm{mg} / \mathrm{kg}$ ) treatment (Koc et al. 2005). According to Nair and Jacob (2016), the $10 \mathrm{mg} /$ $\mathrm{kg}$ dose is used in clinical practice and parallels to $70 \mathrm{mg} /$ $\mathrm{m}^{2}$ in a human being $(60 \mathrm{~kg})$.

Dodecanal and decanal, the two main aldehydes which constitutes to the flavour of P. minus were found as most-concentrated compound in the essential oil used in this study. Our findings were similar to Ahmad et al. (2014), Baharum et al. (2010) and Rusdi et al. (2016). Ahmad et al. (2014) also found most of the terpenoids identified by GC-MS were majorly present in leaves compared to the stems and roots because aerial parts of the plant are exposed to oxidative stress, high temperatures and have a photosynthetic function. According to Opitz 


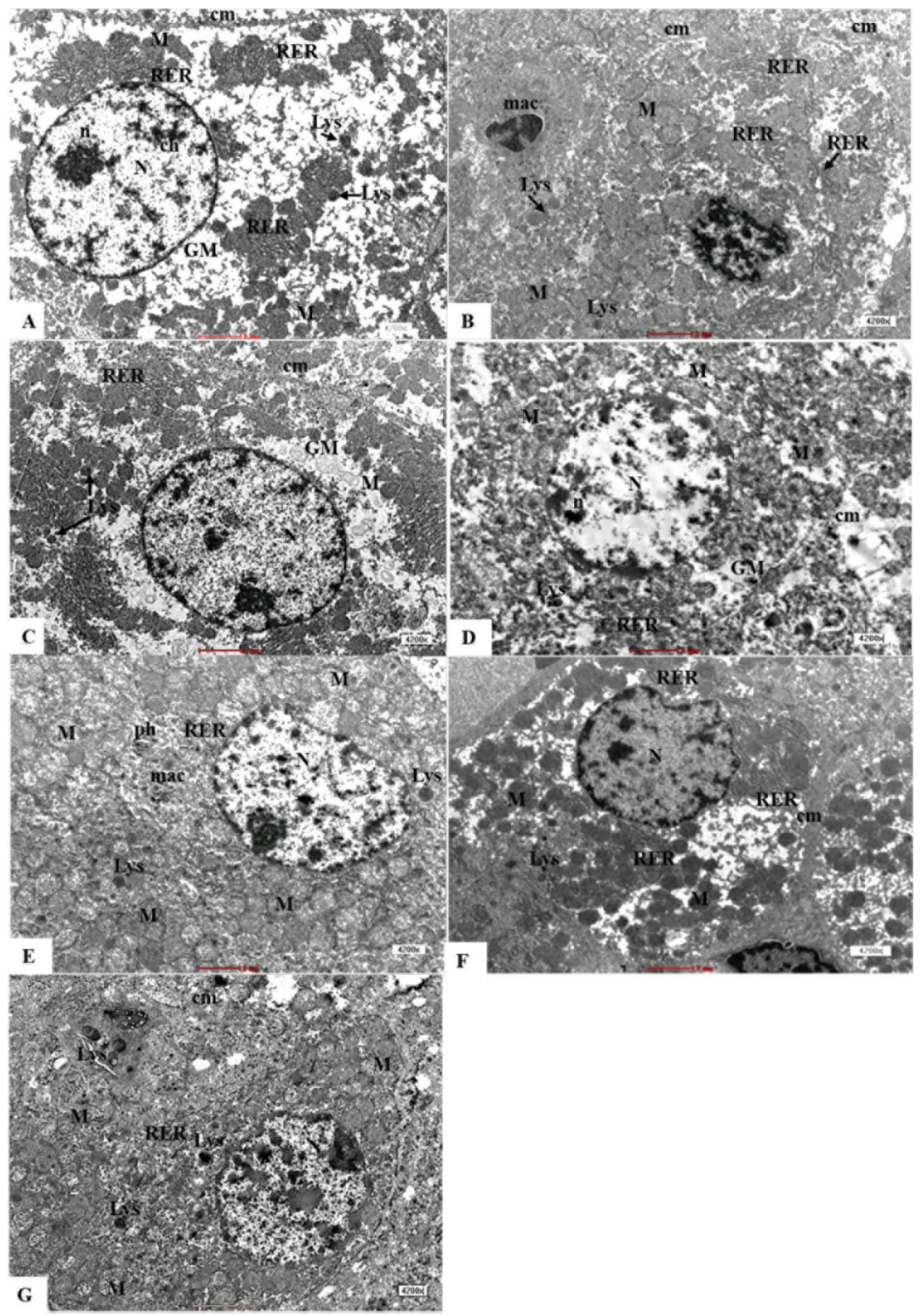

FIGURE 5. Ultrastructural changes in the liver of rats. (A) The normal hepatocyte has a central oval nucleus (N) with electron dense nucleolus (n). The cytoplasm contains numerous oblong and round-shaped mitochondria (M), few lysosomes (Lys), rough endoplasmic reticulum cisternae (RER) and variable sizes of glycogen masses (GM) located between the mitochondria. The biliary surface of the hepatocyte membrane $(\mathrm{cm})$ also can be seen. Condensed heterochromatin masses (ch) were seen within the nucleoplasm and deposited on the inner aspect of the nuclear envelope; (B) A small-sized polygonal hepatocyte having a central irregular nucleus is seen in the $\mathrm{CP}$ group. The cytoplasm contains variable-sized of round and oblong-shaped mitochondria and dilated of rough endoplasmic reticulum, lysosomes. Macrophage (mac) also can be seen; (C) BCP group shows a similar normal hepatocyte as control group; (D) The polygonal hepatocytes being similar to the normal liver with the exception of a high mitochondrial number in the PmEO100CP group. The cytoplasm contains numerous oval and oblong mitochondria, rough endoplasmic reticulum and lysosome. The cell has a central oval nucleus with nucleolus, masses heterochromatin and cell membrane also can be seen; (E) PmEO200CP shows irregular structure of nucleus, increase number of round and oblong shape mitochondria, phagosome (ph) and macrophage also can be seen; (F) Small-sized of hepatocytes, vesicular dilated of RER and thick hepatocyte membrane were seen in PmEO400CP group; and (G) PmEO400 group shows a central irregular nucleus with a defect in its envelope. The cytoplasm contains variable size of mitochondria and lysome

et al. (2008), a large variety of terpenes are produced in all photosynthetically active parts of the plants and stored in the subepidermal gland. Furthermore, Peñuelas and Llusiá (2002) stated that temperature increases the emission and production rates of most terpenes and can replace photorespiration of the plant in protection from photodamage by scavenging oxygen-reactive species; likely explaining our observations in this study.

Abdelhafiz et al. (2014), Cetin et al. (2011) and Dkhil et al. (2013) and stated that using a plant-derived-material can protect against cisplatin-induced hepatotoxicity. $P$. minus is one of those candidate plants due to high level of 
antioxidants, terpenoids and phenolic compounds including a-humulene, a-curcumene, $\beta$-caryophyllene, d-cadinene, farnesol and nerolidol that exhibit several bioactive properties (Ahmad et al. 2014; Baharum et al. 2010). BCP found in the essential oils of spices and medicinal plants such as cloves, origanum and cinnamon and black pepper (Gertsch et al. 2008); is a FDA-approved food additive, antioxidant (Bridgeman \& Abazia 2017), antiinflammatory agent (Gertsch et al. 2008) and antispasmodic agent (Leonhardt et al. 2010). BCP effectively improved cisplatin-induced nephrotoxicity in a cannabinoid 2 receptor-dependent manner (Calleja et. al. 2012) and the antioxidant effect of $\mathrm{BCP}$ protected rat liver from carbontetrachloride-induced fibrosis (Hovárth et. al. 2012); and therefore was used as positive control in this study. Dose of $\mathrm{BCP}$ and PmEO is according to previous study by Cho et al. (2007) and Damião et al. (2013), respectively.

The present study found that a single dose of cisplatin $(10 \mathrm{mg} / \mathrm{kg})$ induced toxicity symptoms including lacrimation, piloerection, hypoactivity and reduced food and drink intake in rats. In accordance with the present results, Abdelmeguid et al. (2010) also found that rats became slightly nervous, less active and exhibited minimal loss of furring after a single injection of cisplatin. Cisplatin also significantly decreased the body weights in the treated rats compared to the controls. Leite et al. (2009) also found that mice treated with high doses of cisplatin showed the extreme loss of body weight and postponed their recovery time. Chirino et al. (2004) also found the decrease of body weight in male rats after 3 days of single of i.p. injection of cisplatin. Reduction in body weight of cisplatin-induced rats might be a result of gastrointestinal dysfunction and toxicity (Mora et. al. 2003). According to King and Perry (2001), cisplatin-treatment might have contributed to weight loss in the rats. Likewise, Park et al. (2009) also found that the decrease of the body weight in cisplatin-induced rats may be because of tissue injury and reduction of their function. Moreover, the reduction in body weight of the animals in this study can be correlated with the decreased food intake observed during experimental period. In this study, the mean body weight of BCP and PmEO-treated rats also significantly decreased on the day 17 and 18 compared to the control group; suggesting treatments were unable to prevent cisplatin-induced weight reduction.

Cisplatin-induced hepatotoxicity is often characterized by minor-to-average increase in serum transaminases, and less frequently by average increase in serum alkaline phosphatase, bilirubin, $g$-glutamyl transpeptidase and lactate dehydrogenase levels. The serum levels of ALT and AST act as oblique assessment of liver condition because these enzymes are normally found in the cytoplasm and are only secreted into the circulation after hepatic damage (McGill 2016). In the present study, the capability of BCP, PmEO100CP and PmEO200CP in ameliorating the cisplatin-induced hepatotoxicity was observed from lowered level of transaminase enzymes in serum compared to cisplatin-induced rats. The amelioration of liver enzymes might be attributed to the effect of BCP, PmEO100CP and PmEO200CP on the hepatocyte cell death and membrane rupture, preventing AST and ALT leakage into the circulation. Unfortunately, PmEO400CP also significantly elevated ALP, AST and ALT compared to the control, BCP and PmEO100CP-treated rats. The dose of $400 \mathrm{mg} / \mathrm{kg}$ of PmEO might have potentiated cisplatin toxicity. Prapapan et al. (2013) also reported that levels of transaminase enzymes depend on the dose of sesquiterpenes zederone, isolated from Curcuma elata where the highest dose (200 $\mathrm{mg} / \mathrm{kg}$ ) showed high level of transaminase enzymes and total bilirubin levels.

In the present study, a significant reduction in GSH levels, GPx, CAT and SOD enzyme activity with increased MDA level was observed in PmEO200CP and PmEO400CP and the better results were observed at the dose of $100 \mathrm{mg} /$ $\mathrm{kg}$ and BCP treatment in rats. Similarly, Christapher et al. (2016) has confirmed that $P$. minus methanol extract had protective effect at dose of below $200 \mathrm{mg} / \mathrm{kg}$ on carbon tetrachloride-induced hepatotoxicity. Iseri et al. (2007) and Mansour et al. (2006) showed a significant difference of oxidative stress biomarker (GSH, GPx, CAT, SOD and MDA in cisplatin-induced rats. The production of ROS induced severe cell damage and membrane permeability mediated by oxidative stress (Iseri et al. 2007). Therefore, cisplatininduced liver toxicity can be improved by increasing antioxidant such as GSH, GPx, CAT and SOD, as seen in this study (Palipoch et al. 2014). However, high dose of sesquiterpenes in PmEO200CP and PmEO400CP can become pro-oxidants in excessive concentration of their free form by reduction of its oxidized metal ions (Lee et al. 2013); suggesting why oxidative stress in essential oiltreated groups were lower in PmEO100CP compared to and PmEO400CP groups.

Protein carbonyl is a biomarker for protein oxidation. The present study found that protein carbonyl content is significantly increased in cisplatin and PmEO400CPtreated rats compared to the control and $\mathrm{BCP}$-treated rats. According to Waseem et al. (2017), protein carbonylation indicates oxidative protein damage resulting from cisplatin-induced oxidative stress. PmEO100CP and BCP pre-treated rats significantly restored protein carbonyl content in the liver similar to the role of natural product on protein carbonylation previously shown by Mohamed et al. (2013). 8-OHdG is the most significant indicator of DNA damage (Koyuncu et al. 2017). According to Cadet (2014), hydrogen from nucleic acids being eliminated by hydroxyl radicals or reacted with double bonds may lead to production of $8-\mathrm{OHdG}$. Our results demonstrated that 8 -OHdG is significantly increased in cisplatin-treated rats as compared to the control group. Previous studies showed that DNA damage was significantly inhibited by pre-treatment with natural compounds (Ince et al. 2014; Koyuncu et al. 2017). PmEO100CP and BCPlikely used its antioxidant activity and decreased ROS-mediated $8-\mathrm{OHdG}$ production.

In the present study, the biochemical and oxidative stress results were confirmed by histological observations. 
Similar to El-Sayyad et al. (2009), this study also found many histological abnormalities including inflammatory infiltration, marked disruption of hepatic cords and dilated blood sinusoids in the rat livers following cisplatin injection. BCP and PmEO100CP ameliorated most of these findings. However, PmEO200CP were more deleterious compared to PmEO100CP whereby mild dilated blood sinusoids, increasing number of binucleated hepatocytes and Kupffer cells were observed. PmEO400CP also showed similar destruction of hepatocytes as in the cisplatin-induced rats. This might be due to the presence of some sesquiterpenes in high concentration as stated by Prapapan et al. (2013). At a dose of $200 \mathrm{mg} / \mathrm{kg}$, hepatocytes necrosis was spread toward the portal area and accompanied by major haemorrhage. Furthermore, Prapapan et al. (2013) also suggested the potentiation of zederone (sesquiterpene)-induced liver toxicity involved the induction of cytochrome P450 that leads to the formation of biological reactive metabolites and oxidative stress. Ultrastructural study also showed that hepatocytes with vesicular dilated RER, irregular nuclei and many small mitochondria in the cisplatin-induced rats, PmEO200CP and PmEO400CP groups. Additionally, mitochondrial number in the cisplatin, PmEO200CP and PmEO400CP group were increased, varying from small round to long rod shaped.

\section{CONCLUSION}

In conclusion, the results of the present study showed that, PmEO100CP restored the biochemical, histological and ultrastructural changes of cisplatin-induced liver toxicity in rats. PmEO100CP protected against cisplatininduced hepatotoxicity in part through their antioxidant activity. Further studies are warranted to explore the precise mechanism underlying the preventive effect of PmEO100CP.

\section{ACKNOWLEDGEMENTS}

This study was funded by the Ministry of Education, Malaysia (Higher Education) (Grant number: FRGS/2/2014/ SKK01/UKM/02/1). Norhashima Abd Rashid is supported by MyBrain15 (MyPhd) scholarship from the Ministry of Education, Malaysia. The authors also thank Mohd Rafizul Mohd Yusof and staff of Department of Anatomy, PPUKM for their technical advice.

\section{REFERENCES}

Abdelhafiz, H.A., El-Kott, A.F. \& Elesh, M.R. 2014. Hepatoprotective effect of royal jelly against cisplatininduced biochemical, oxidative stress, anti-oxidants and histopathological abnormalities. Adv. Life Sci. Technol. 27: 28-38.

Abdelmeguid, N., Nakkash, H. \& Abou Zeinab, N. 2010. Silymarin ameliorates cisplatin-induced hepatotoxicity in rats: Histopathological and ultrastructural studies. PJBS 13: 463-479.
Ahmad, R., Baharum, S.N., Bunawan, H., Lee, M., Noor, N.M., Rohani, E.R., Ilias, N. \& Zin, N.M. 2014. Volatile profiling of aromatic traditional medicinal plant, Polygonum minus in different tissues and its biological activities. Molecules 19: 19220-19242.

Al-Malki, A.L. \& Sayed, A.A.R. 2014. Thymoquinone attenuates cisplatin-induced hepatotoxicity via nuclear factor kappa-B. BMC Complement. Altern. Med. 14(1): 282.

Attyah, M.A. \& Ismail, H.S. 2017. Protective effect of ginger extract against cisplatin-induced hepatotoxicity and cardiotoxicity in rats. Iraqi J. Pharm. Sci. 21(1): 27-33.

Baharum, S.N., Bunawan, H., Ghani, M.A.A., Mustapha, W.A.W. \& Noor, N.M. 2010. Analysis of the chemical composition of the essential oil of Polygonum minus Huds. using twodimensional gas chromatography-time-of-flight mass spectrometry (Gc-Tof Ms). Molecules 15(10): 7006-7015.

Barabas, K., Milner, R., Lurie, D. \& Adin, C. 2008. Cisplatin: A review of toxicities and therapeutic applications. Vet. Comp. Oncol. 6(1): 1-18.

Bridgeman, M.B. \& Abazia, D.T. 2017. Medicinal cannabis: History, pharmacology, and implications for the acute care setting. Pharm. Ther. 42(3): 180-188.

Cadet, J. 2014. Sfrr-E basic science lecture (Elsevier sponsored) oxidative degradation pathways of cellular DNA: Product formation and mechanistic insights. Free Radic. Biol. Med. 75(1): S2. https://doi.org/10.1016/j. freeradbiomed.2014.10.598.

Calleja, M.A., Vieites, J.M., Montero-Meterdez, T., Torres, M.I., Faus, M.J., Gil, A. \& Suárez, A. 2012. The antioxidant effect of $\beta$-caryophyllene protects rat liver from carbon tetrachloride-induced fibrosis by inhibiting hepatic stellate cell activation. Brit. J. Nutrition 109(3): 394-401.

Cetin, A., Arslanbas, A., Saraymen, B., Canoz, O., Ozturk, A. \& Sagdic, O. 2011. Effects of grape seed extract and Origanum onites essential oil on cisplatin-induced hepatotoxicity in rats. Int. J. Hematol. Oncol. 21(3): 133-140.

Chirino, Y.I., Hernández-Pando, R. \& Pedraza-Chaverí, J. 2004. Peroxynitrite decomposition catalyst ameliorates renal damage and protein nitration in cisplatin-induced nephrotoxicity in rats. BMC Pharmacol. 4: 20. https://doi. org/10.1186/1471-2210-4-20.

Cho, J.Y., Chang, H.J., Lee, S.K., Kim, H.J., Hwang, J.K. \& Chun, H.S. 2007. Amelioration of dextran sulfate sodium-induced colitis in mice by oral administration of B-caryophyllene, a sesquiterpene. Life Sci. 80(10): 932-939.

Christapher, P.V., Sin Joe, L., Tian, M., Sethi Brij Mohan, T., Parasuraman, S., Al-Suede, F. \& Murugaiyah, V. 2016. Evaluation of methanol extract of Polygonum minus Huds. leaves for its hepatoprotective activity. Malay. J. Microbiol. 12: 345-352.

Dahham, S., Tabana, Y., Iqbal, M., Ahamed, M., Ezzat, M., Majid, A. \& Majid, A. 2015. The anticancer, antioxidant and antimicrobial properties of the sesquiterpene B-caryophyllene from the essential oil of Aquilaria crassna. Molecules 20(7): 11808-11829.

Damião, M.J., Giannocco, G., Grespan, R., Silva, E.L., Duarte, J.S. \& Marciel, R.M. 2013. Ginger essential oil ameliorates cisplatin-induced nephrotoxicity in mice. Trop. J. Pharm. Res. 12(6): 959-965.

Desoize, B. 2002. Cancer and metals and metal compounds: Part I-Carcinogenesis. Crit. Rev. Oncol. Hematol. 42(1): 1-3.

Devi, H.P., Mazumder, P.B. \& Devi, L.P. 2015. Antioxidant and antimutagenic activity of Curcuma caesia roxb. rhizome extracts. Toxicol. Rep. 2: 423-428. 
Dkhil, M.A., Al-Quraishy, S., Aref, A.M., Othman, M.S., ElDeib, K.M. \& Abdel Moneim, A.E. 2013. The potential role of Azadirachta indica treatment on cisplatin-induced hepatotoxicity and oxidative stress in female rats. Oxid. Med. Cell. Longev. 2013: 741817.

Ebada, M.E. 2018. Essential oils of green cumin and chamomile partially protect against acute acetaminophen hepatotoxicity in rats. Anais da Academia Brasileira de Ciências 90: 23472358.

El-Sayyad, H.I., Ismail, M.F., Shalaby, F.M., Abou-El-Magd, R.F., Gaur, R.L., Fernando, A., Raj, M.H.G. \& Ouhtit, A. 2009. Histopathological effects of cisplatin, doxorubicin and 5-Flurouracil (5-Fu) on the liver of male albino rats. Int. J. Biol. Sci. 5(5): 466-473.

Fernandes, E.S., Passos, G.F., Medeiros, R., Da Cunha, F.M., Ferreira, J., Campos, M.M., Pianowski, L.F. \& Calixto, J.B. 2007. Anti-inflammatory effects of compounds alphahumulene and (-)-trans-caryophyllene isolated from the essential oil of Cordia Verbenacea. Eur. J. Pharmacol. 569(3): 228-236.

Gertsch, J., Leonti, M., Raduner, S., Racz, I., Chen, J.Z., Xie, X.Q., Altmann, K.H., Karsak, M. \& Zimmer, A. 2008. Betacaryophyllene is a dietary cannabinoid. Proc. Natl. Acad. Sci. U.S.A 105(26): 9099-9104.

Hamid, A., Say Lee, L., Ridzuan Karim, S. \& Farhana Jufri, N. 2018. Hepatoprotective effects of zerumbone against paracetamol-induced acute hepatotoxicity in rats. Malays. J. Med. Sci. 25: 64-71.

Horváth, B., Mukhopadhyay, P., Kechrid, M., Patel, V., Tanashian, G., Wink, D.A., Gertsch, J. \& Pacher, P. 2012. $\beta$-Caryophyllene ameliorates cisplatin-induced nephrotoxicity in a cannabinoid 2 receptor-dependent manner. Free Radic. Biol. Med. 52(8): 1325-1333.

Hussan, F., Mansor, A.S., Hassan, S.N., Kamaruddin, T.N.T., Budin, S.B. \& Othman, F. 2015. Anti-inflammatory property of Plantago major leaf extract reduces the inflammatory reaction in experimental acetaminophen-induced liver injury. Evid-Based Complementary Altern. Med. 2015: 347861.

Idris, M.H.M., Budin, S.B., Osman, M. \& Mohamed, J. 2012. Protective role of Hibiscus sabdariffa calyx extract against streptozotocin induced sperm damage in diabetic rats. EXCLI Journal 11: 659-669.

Ince, S., Acaroz, A.D., Neuwirth, O., Demirel, H.H., Denk, B., Kucukkurt, I. \& Turkmen, R. 2014. Protective effect of polydatin, a natural precursor of resveratrol, against cisplatininduced toxicity in rats. Food Chem. Toxicol. 72: 147-153.

İşeri, S., Ercan, F., Gedik, N., Yüksel, M. \& Alican, İ. 2007. Simvastatin attenuates cisplatin-induced kidney and liver damage in rats. Toxicol. 230(2): 256-264.

Kart, A., Cigremis, Y., Karaman, M. \& Ozen, H. 2010. Caffeic acid phenethyl ester (Cape) ameliorates cisplatin-induced hepatotoxicity in rabbit. Exp. Toxicol. Pathol. 62(1): 45-52.

Katzung, B.G. 2004. Basic and Clinical Pharmacology. New York: McGraw-Hill.

Khan, N. \& Sultana, S. 2005. Inhibition of two stage renal carcinogenesis, oxidative damage and hyperproliferative response by Nigella sativa. Eur. J. Cancer Prev. 14(2): 159-168.

King, P.D. \& Perry, M.C. 2001. Hepatotoxicity of chemotherapy. Oncologist 6(2): 162-176.

Koc, A., Duru, M., Ciralik, H., Akcan, R. \& Sogut, S. 2005. Protective agent, erdosteine, against cisplatin-induced hepatic oxidant injury in rats. Mol. Cell Biochem. 278(1): 79-84.
Koyuncu, I., Kocyigit, A., Gonel, A., Arslan, E. \& Durgun, M. 2017. The protective effect of naringenin-oxime on cisplatininduced toxicity in rats. Biochem. Res. Int. 2017: 9478958.

Lee, W.L., Huang, J.Y. \& Shyur, L.F. 2013. Phytoagents for cancer management: Regulation of nucleic acid oxidation, ROS, and related mechanisms. Oxid. Med. Cell. Longev. 2013: 925804.

Lee Ke Yao, Sarah Liana Abdul Razak, Nazhirah Ismail, Ng Chun Fai, Mohd. Hafis Asyraf Muhamad Asgar, Nursyahirah Mohd Sharif, Goon Jo Aan \& Zakiah Jubri. 2011. Malaysian gelam honey reduces oxidative damage and modulates antioxidant enzyme activities in young and middle aged rats. J. Med. Plants Res. 5: 5618-5625.

Leite, E.A., Dos Santos Giuberti, C., Wainstein, A.J.A., Wainstein, A.P.D.L., Coelho, L.G.V., Lana, Â.M.Q., Savassi-Rocha, P.R. \& De Oliveira, M.C. 2009. Acute toxicity of long-circulating and $\mathrm{pH}$-sensitive liposomes containing cisplatin in mice after intraperitoneal administration. Life Sci. 84(19): 641-649.

Leonhardt, V., Leal-Cardoso, J.H., Lahlou, S., Albuquerque, A.a.C., Porto, R.S., Celedônio, N.R., Oliveira, A.C., Pereira, R.F., Silva, L.P., Garcia-Teófilo, T.M.N., Silva, A.P.F.S., Magalhães, P.J.C., Duarte, G.P. \& Coelho-De-Souza, A.N. 2010. Antispasmodic effects of essential oil of Pterodon polygalaeflorus and its main constituent B-caryophyllene on rat isolated ileum. Fundam. Clin. Pharmacol. 24(6): 749-758.

Liao, Y., Lu, X., Lu, C., Li, G., Jin, Y. \& Tang, H. 2008. Selection of agents for prevention of cisplatin-induced hepatotoxicity. Pharmacol. Res. 57(2): 125-131.

Mansour, H.H., Hafez, H.F. \& Fahmy, N.M. 2006. Silymarin modulates cisplatin-induced oxidative stress and hepatotoxicity in rats. J. Biochem. Mol. Biol. 39(6): 656-661.

Mohamed, J., Shing, S.W., Idris, M.H.M., Budin, S.B. \& Zainalabidin, S. 2013. The protective effect of aqueous extracts of roselle (Hibiscus sabdariffa L. UKMR-2) against red blood cell membrane oxidative stress in rats with streptozotocin-induced diabetes. Clinics 68: 1358-1363.

Mora, L.D.O., Antunes, L.M.G., Francescato, H.X., Sa Della, C. \& Bianchi, M.D.L.P. 2003. The effects of oral glutamine on cisplatin-induced nephrotoxicity in rats. Pharmacol. Res. 47(6): 517-522.

Nair, A.B. \& Jacob, S. 2016. A simple practice guide for dose conversion between animals and human. J. Basic Clin. Pharm. 7(2): 27-31.

Nasr A.Y. 2014. Protective effect of aged garlic extract against the oxidative stress induced by cisplatin on blood cells parameters and hepatic antioxidant enzymes in rats. Toxicol. Rep. 1: 682-691.

Nasr, A.Y. 2013. Morphological, biochemical, histological, and ultrastructural protective effects of misoprostol on cisplatin induced-hepatotoxicity in adult male rats. Saudi Med. J. 34(12): 1237-1247.

Opitz, S., Kunert, G. \& Gershenzon, J. 2008. Increased terpenoid accumulation in cotton (Gossypium hirsutum) foliage is a general wound response. J. Chem. Ecol. 34(4): 508-522.

Pabla, N. \& Dong, Z. 2008. Cisplatin nephrotoxicity: Mechanisms and renoprotective strategies. Kidney Int. 73(9): 994-1007.

Palipoch, S. \& Punsawad, C. 2013. Biochemical and histological study of rat liver and kidney injury induced by cisplatin. $J$. Toxicol. Pathol. 26(3): 293-299.

Palipoch, S., Punsawad, C., Koomhin, P. \& Suwannalert, P. 2014. Hepatoprotective effect of curcumin and alpha-tocopherol against cisplatin-induced oxidative stress. BMC Complemen. Altern. Med. 14: 111. 
Park, H.R., Ju, E.J., Jo, S.K., Jung, U., Kim, S.H. \& Yee, S.T. 2009. Enhanced antitumor efficacy of cisplatin in combination with hemohim in tumor-bearing mice. BMC Cancer 9(1): 85 .

Peñuelas, J. \& Llusià, J. 2002. Linking photorespiration, monoterpenes and thermotolerance in Quercus. New Phytol. 155(2): 227-237.

Prapapan Pimkaew, Kanoknetr Suksen, Koravit Somkid, Ratchanaporn Chokchaisiri, Surawat Jariyawat, Aporn Chuncharunee, Apichart Suksamrarn \& Pawinee Piyachaturawat. 2013. Zederone, a sesquiterpene from Curcuma elata Roxb, is hepatotoxic in mice. Int. J. Toxicol. 32(6): 454-462.

Qader, S.W., Abdulla, M.A., Chua, L.S., Najim, N., Zain, M.M. \& Hamdan, S. 2011. Antioxidant, total phenolic content and cytotoxicity evaluation of selected Malaysian plants. Molecules 16(4): 3433-3443.

Rusdi, N.A., Goh, H.H. \& Baharum, S. 2016. Gc-Ms/ Olfactometric characterisation and aroma extraction dilution analysis of aroma active compounds in Polygonum minus essential oil. Plant Omics Journal 9: 289-291.

Rybak, L.P., Mukherjea, D., Jajoo, S. \& Ramkumar, V. 2009. Cisplatin ototoxicity and protection: Clinical and experimental studies. Tohoku J. Exp. Med. 219(3): 177-186.

Sarhan, M.A.A., Shati, A.A. \& Elsaid, F.G. 2014. Biochemical and molecular studies on the possible influence of the Brassica oleracea and Beta vulgaris extracts to mitigate the effect of food preservatives and food chemical colorants on albino rats. Saudi J. Biol. Sci. 21(4): 342-354.

Schmidt, M. \& Eisenburg, J. 1975. Serum bilirubin determination in newborn infants. A new micromethod for the determination of serum of plasma bilirubin in newborn infants. Fortschr. Med. 93(30): 1461-1466.

Waseem, M., Tabassum, H., Bhardwaj, M. \& Parvez, S. 2017. Ameliorative efficacy of quercetin against cisplatin-induced mitochondrial dysfunction: Study on isolated rat liver mitochondria. Mol. Med. Rep. 16: 2939-2945.
Norhashima Abd Rashid, Asmah Hamid \& Siti Balkis Budin* Biomedical Science Programme

Centre for Applied Health Sciences

Faculty of Health Sciences

Universiti Kebangsaan Malaysia

Jalan Raja Muda Abdul Aziz

50300 Kuala Lumpur, Federal Territory

Malaysia

Nurul Raudzah Adib Ridzuan \& Teoh Seong Lin Department of Anatomy

Faculty of Medicine

Pusat Perubatan Universiti Kebangsaan Malaysia

Jalan Yaacob Latif, Cheras

56000 Kuala Lumpur, Federal Territory

Malaysia

Farida Hussan

Human Biology Department

School of Medicine

International Medical University

Bukit Jalil, 57000 Kuala Lumpur, Federal Territory

Malaysia

*Corresponding author; email: balkis@ukm.edu.my

Received: 22 February 2019

Accepted: 1 July 2019 